\title{
Work Life Balance, Peningkatan Karir dan Tekanan Kerja terhadap Produktivitas: Kasus pada Lembaga Sertifikasi Profesi P3 Pembangun Penyuluh Integritas Bangsa (Work Life Balance, Career Improvement and Work Pressures on Productivity: Case Study at the P3 Professional Certification Institute for National Integrity Extension Builders)
}

Dewi Puspaningtyas Faeni ${ }^{{ }^{*}}$, Ratih Puspitaningtyas ${ }^{2}$, Ravindra Safitra $^{3}$

Fakultas Ekonomi dan Bisnis, Universitas Budi Luhur, Jakarta Selatan ${ }^{1,2,3}$

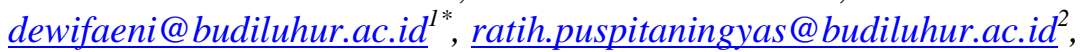
ravindra.safitra@budiluhur.ac.id ${ }^{3}$

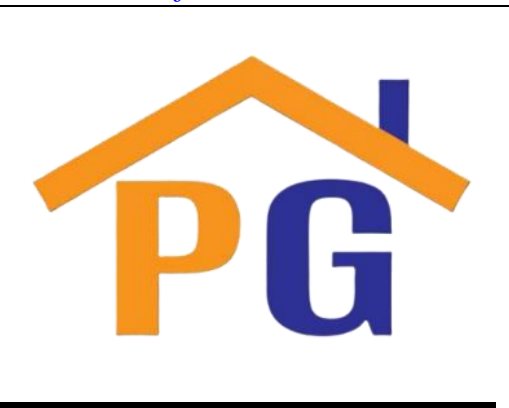

Riwayat Artikel

Diterima pada 30 Agustus 2021

Direvisi pada 7 September 2021

Disetujui pada 9 September 2021

\begin{abstract}
Purpose: This study examined variables aimed at examining work-life balance, Career Improvement and work pressure towards productivity.
\end{abstract}

Research methodology: This study was conducted on employees of LSP P3 PIB, examining of what is the correlation between the correlations of the three exogenous variable factors towards productivity as an endogenous variable. Sampling in this research was calculated using the Slovin formula using the Simple Random Sampling. The Respondents are 105 people, rounded up to 100 people. The respondents were employees of LSP P3 PIB. The methodological technique used for data collection is by distributing questionnaires from the firsthand source or Primary Data. The statistical test tool used is SmartPLS 3.

Results: The conclusion of this study demographically, the majority of the respondent are women. The outcome of this research is that work-life balance $(0.351)$ positively and significantly affects productivity, while Career (0.309) has a significantly positive effect, and stress (0.294) has a significant positive effect on productivity.

Limitations: The limitation is that it is only conducted on variables that are studied and excluding other external variables with a limited number of respondents in less than one year.

Contribution: The organization be more aware of the employees' working engagement by supporting the employees to adjust their work schedule that is Work-Life Balance for their productivity.

Keywords: Work-Life Balance, Career Development, Stress, Productivity

How to Cite: Faeni, D. P., Puspitaningtyas, R., \& Savitra, R. (2021). Work Life Balance, Peningkatan Karir dan Tekanan Kerja terhadap Produktivitas: Kasus pada Lembaga Sertifikasi Profesi P3 Pembangun Penyuluh Integritas Bangsa. Studi Akuntansi, Keuangan, dan Manajemen, 1(1), 45-57.

\section{Pendahuluan}

Pada era globalisasi saat ini, persaingan bisnis semakin meningkat seiring dengan laju pertumbuhan ekonomi global yang dapat diamati dari banyaknya pesaing bisnis yang semakin meluas seperti dalam hal per-saingan produksi, marketing, pengelolaan Sumber Daya Manusia (SDM), serta penagangan 
transaksi antara perusahaan dengan pelanggan, dan perusahaan dengan perusahaan lain. Perusahaan selalu memiliki target yang harus dicapai dalam waktu tertentu kepada pekerjanya. SDM yang tidak memiliki kesanggupan dalam menghadapi tuntutan-tuntutan globalisasi, cenderung menganggap pekerjaan seperti beban dan akan selalu menjalani pekerjaan sebagai tuntutan dan suatu keharusan. Keadaan akhirnya, pekerja tidak merasakan makna kerja, SDM yang menganggap pekerjaan sebagai beban disebut sebagai SDM yang memiliki etos kerja yang rendah. Demi menjaga kualitas, meningkatkan produktivitas, dan menjaga komitmen dari para pekerja yang selalu dituntut untuk mencapai target bisnis yang diberikan perusahaan, pada umumnya banyak perusahaan saat ini menerapkan program Work-Life Balance atau sering disebut sebagai keseimbangan kehidupan kerja pekerja (Ganapathi, 2016).

Tujuan dari riset ini adalah untuk mengetahui korelasi antara variable-variabel Work Life Balance, Tekanan Kerja, Peningkatan karier terhadap Produktivitas para pekerja, seberapa besar variablevariabel ter-sebut saling mempengaruhi dan seberapa signifikan korelasi terhadap masing-masing variable pada produk-tivitasnya. Pekerja yang memiliki work life balance, apabila dalam keadaan bahagia dan gembira saat bekerja baik di tempat kerja maupun di dalam kehidupan pribadi. Work life balance dipersepsikan sebagai tingkat kepuasaan dalam menjalankan keduanya yaitu pekerjaan dan kehidupan pribadi (Ariawati et al., 2019).

Selain dari work life balance strategi perusahaan dalam membuat pekerja merasa nyaman dengan pekerjaannya untuk meningkatkan produktivitas yang terkait dengan peningkatan karir. Peningkatan karir yang sistematis, terancangandengan baik mencetak perusahaan lebih unggul dalam lingkungan bisnis yang semakin kompetitif dan terkemuka. Perusahaan yang memberikan kesempatan kepada pekerja untuk meningkatkan karir serta kemampuannya dengan optimal, membuat pekerja sangat dihargai, men-imbulkan rasa bahagia lahir bathin dan senang akan pekerjaan yang dijalani (Wuarlima et al., 2019). Perusahaan perlu mengelola dan mengembangkan karir dengan baik supaya produktivitas tetap terjaga dan mendorong pekerja untuk melakukan hal yang terbaik untuk perusahaan, memiliki semangat kerja, dan menghindari tekanan kerja yang dapat menurunkan produktivitas (Alamsyah, 2019).

Faktor lain yang berpengaruh terhadap produktivitas adalah tekanan kerja. Tekanan kerja dipersepsikan sebagai sebuah keadaan dimana seorang yang mengalami ketegangan yang berpengaruh pada pikiran, perasaan, dan keadaan fisiologis. Timbulnya tekanan kerja bisa jadi, kare-ana kelebihan beban kerja, yang berdampak pada menurunnya produktivitas serta hilangnya minat pekerja dalam bekerja. Beberapa dampak negatif yang ditimbulkan dari tekanan kerja terhadap pe-rusahaan, antara lain: dapat menurunkan profitabilitas serta penurunan pendapatan perusahaan ka-rena terdapat ketidak seimbangan antara produktivitas dengan biaya yang dikeluarkan untuk mem-bayar gaji, tunjangan, biaya pengobatan, biaya-biaya lain dan fasilitas kerja (Sutrisno et al., 2019). Perusahaan wajib memiliki strategi pendekatan untuk menurunkan tingkat tekanan kerja, beberapa strategi pendekatan yang dilakukan perusahaan berupa peningkatan iklim lembaga, pimpinan melakukan analisis dan kejelasan tugas yang akan diberikan kepadanya, menyediakan sarana fit-ness, mengajak pekerja untuk ikut relaksasi, melibatkan di setiap pengambilan keputusan, serta pendekatan individu dengan meningkatkan keimanan, dan mengelola work life balance dengan op-timal (Harahap, 2020).

Penilaian SDM dilihat dari produktivitasnya, SDM yang efektif menghasilkan produktivitas yang tinggi. Pencapaian tujuan perusahaan, wajib memperhatikan produktivitas pekerja. Terminolo-gi produktivitas yaitu komparasi antara input (masukan) dan output (hasil). Pekerja dapat dikatakan produktif, apabila menghasilkan barang atau jasa dalam jangka waktu yang singkat atau tepat sesuai dengan waktu yang ditentukan perusahaan. Tenaga yang dikeluarkan lebih kecil dibandingkan dengan hasil pekerjaannya dapat dikatakan pekerja tersebut produktif. Produktivitas dapat didukung dengan pengelolaan work life balance yang baik, perusahaan memberikan peningkatan karir yang terstruktur, dan melakukan pendekatan untuk mengurangi tingkat tekanan kerja (Kurnia et al., 2019). 
Work life balance, peningkatan karir dan pengelolaan tekanan kerja sangat penting bagi se-tiap perusahaan agar produktivitas tetap terjaga dan tercapainya target perusahaan, termasuk Lem-baga Sertifikasi Profesi Pembangun Penyuluh Integritas Bangsa - Badan Nasional Sertifikasi Profesi (LSP P3 PIB). Pada saat pandemi Covid-19 yang menimpa Indonesia, dengan adanya social distan-cing dan work from home dapat menimbulkan tekanan kerja dan menyebabkan jadwal kerja yang mundur. Pencapaian target kerja LSP P3 PIB mundur serta terjadi penumpukkan tugas kerja. LSP P3 PIB memiliki target 3.000 sertifikasi pada tahun 2020. Asesor yang bekerja di LSP P3 PIB masih bekerja tenang dan bahagia, serta menjadikan beban kerja dan tekanan kerja menjadi bagian dari motivasi kerja, oleh karena keadaan yang fenomenal ini, maka perlu dilakukan riset untuk mendeteksi mengapa dengan beban kerja yang luar biasa tinggi, pencapaian target yang ketat, tetapi para Aseso bekerja diatas target atau Key Performance Indicator (KPI) dan semua asesor merasa kompak dan bahagia saat bekerja.

Limitasi dari riset ini adalah, bahwa kajian hanya dilakukan seputar variable yang diteliti dan tidak meneliti di luar variable lain,serta jumlah responden yang terbatas serta dilaksankan pada kurun waktu kurang dari satu tahun kerja

\section{Tinjauan Pustaka dan Pengembangan Hipotesis Work-life Balance}

Penelitian Work-life balance merupakan suatu keadaan saat pekerja dapat mengklasifikasi antara akuntabilitas kerja, kehidupan pribadi serta jenis tanggung jawab lainya. Keadaan ini sangat dibutuhkan untuk menjaga stabilitas atau equilibrium antara permasalahan kerja dan perseteruan pribadi di dalam ke-hidupan sehari-hari. Simplifikasi dari keadaan tersebut adalah saat seorang pekerja secara fleksible mengalokasikan waktu dan energi secara balance atau seimbang antara kehidupan pribadi, waktu rehat, kehidupan pribadi serta pekerjaan. Apabila pekerja memiliki work life balance, maka ia mampu menjadi pribadi yang omnipotent atau sangat produktif. Keadaan seperti ini dirasakan san-gat seimbang, karena adanya kepuasan antara kebahagiaan hidup dan produktifitas kerja. Se-baliknya, secara resiprokal apabila pekerja menghadapi kesulitan dalam mengklasifikasi antara pembagian kepuasan kerja dengan kebahagiaan hidup, maka dapat dipastikan ia akan memiliki produktifitas kerja yang rendah hal mana menjadi penyebab munculnya tekanan kerja. Pekerja dapat mengatur dan membagi antara tanggung jawab pekerjaan, kehidupan pribadi dan tanggung jawab lainnya. Keadaan tersebut menghindarkan kita dari perseteruan antara kehidupan pribadi dengan pekerjaan. Dengan kata lain, ini adalah suatu keadaan di mana seorang pekerja bisa menga-tur waktu dan energi yang seimbang antara pekerjaan, kebutuhan pribadi, rekreasi, dan kehidupan pribadi. Work-life balance, memungkinkan seorang pekerja dapat menjadi lebih produktif karena terdapat equilibrium antara pekerjaan dan kehidupan pribadi. Ini dikarenakan keadaan yang dirasa-kan orang tersebut cukup mendukung dan meningkatkan kepuasannya dalam melakukan peker-jaan. Disamping itu, ia juga menjadi lebih kreatif karena memiliki waktu, energi, atau modal lebih untuk melakukan hal yang ia senangi. Sebaliknya, jika pekerja tidak memiliki work-life bal-ance yang baik, kinerjanya cenderung merosot dan bisa merusak bidang kehidupan lainnya. Umumnya, hal ini disebabkan oleh tingginya tuntutan pekerjaan era sekarang ini (Schabracq, 2017).

Pencapaian work-life balance, dapat memicu produktifitas tinggi dan mengekplorasi kege-maran ataupun keterampilan diluar pekerjaan orang tersebut. Secara otomatis akan membuat peker-ja bahagia dalam kehidupan sehari-hari yang berdampak pada positifitas di dalam menjalani peker-jaan secara optimal. Khususnya para milenial, disaat mencari pekerjaan biasanya mencari pekerjaan yang serius tapi santai memiliki usur keleluasaan berekpresi dan kebahagiaan menjalaninya di da-lam scope pekerjaan. Pekerja dapat lebih produktif dan mengeksplorasi hobi atau kemampuan di luar pekerjaan. Ini akan membuat pekerja lebih bahagia dalam menjalani pekerjaan.

Bagi generasi milenial work-life balance berkaitan dengan kemampuan pekerja dalam me-menuhi gaya hidup melalui pekerjaan yang dilakukan. Bagi pekerja dari generasi milenial, pemenu-han gaya hidup berpengaruh pada tingkat kebahagiaan mereka, sebab itu milenial akan mencari ka-rier yang dapat memenuhi gaya hidupnya. Generasi milenial akan mencari pekerjaan sehingga ia dapat tampil sebagai pekerja yang memegang posisi yang penting, memiliki fasilitas dari peker-jaannya yang 
nyaman, berpenghasilan tinggi, memiliki gaya hidup yang high class akan memiliki dampak yang positive terhadap self image pekerja tersebut. Baik di lingkungan keluarga maupun di lingkungan profesionalnya. Di luar itu, mencapai work-life balance sendiri memiliki manfaat lain (Forbes, 2018).

Work-life balance menciptakan kehidupan yang seimbang secara psikosomatis, psiko ada-lah pikiran dan somatic adalah tubuh. Saat pikiran seseorang terganggu karena tekanan kerja, maka tubuhnya akan terganggu. Pikiran yang tidak seimbang yang disebabkan oleh ketidak puasan kerja serta beban psikososial yang tinggi akan memunculkan keluhan rasa sakit pada tubuh, dengan demikian akan timbul adanya defisit kebahagiaan yang dipicu oleh ketidak seimbangan jiwa. Yang memicu penurunan kinerja. Kebahagiaan dan keseimbangan mampu membuat pekerja menjadi lebih kuat dan positif dalam berpikir, yang mana mampu meningkatkan optimisme kerja. Pikiran yang positif akan meningkatkan imun tubuh yang tinggi, sehingga orang tersebut dapat terlindungi dari berbagai macam penyakit. Bahkan keseimbangan dan kebahagiaan batin mampu menghindar-kan pekerja dari gangguan kejiwaan mental. Dengan hati dan pikiran yang positif pekerja dapat menjadi loyal, berdedikasi, memiliki komitmen dan tidak merasa dalam tekanan dalam mengerjakan sesuatu.

Work Life Balance atau keseimbangan antara pekerjaan dalam kehidupan sehari-hari mampu menstimulus ide-ide inovatif dengan adanya terobosan-terobosan sebagai bentuk wujud nyata dari produktifitas tinggi. Sebagai sebuah manifestasi dari rasa komitmen yang tinggi dan pencapaian optimal.

Work life balance mampu mengiring orang menjadi lebih focus terhadap pekerjaannya, berkomitmen, berdedikasi penuh sebagai totalitas dari kebahagiaan dan kepuasan dirinya. Disamping itu, work life balance memiliki kemanfaatan ganda yaitu mampu mengurangi kejenuhan, tekanan kerja dan selalu berdampak positif di dalam setiap langkah dan pekerjaannya (Schabracq, 2017).

Hal-hal yang dapat mempengaruhi work-life balance seorang pekerja (Schabracq, 2017) adalah sebagai berikut:

1. Kepribadian Pekerja

Pekerja yang memiliki background pribadi yang harmonis dan seimbang cenderung memilik Work_life balance yang jauh lebih baik. Mereka cenderung mengikuti apa yang telah mereka alami dengan baik di dalam kehidupan pribadi mereka. Lebih tenang, aman dan nyaman menjalani hidup yang baik sangat mendalam mempengaruhi kepribadian mereka. Kehadiran pribadi yang hangat menjadikan seorang pekerja menjadi berfungsi lebih baik secara personal maupun profesional. Pekerja dengan background pribadi yang harmonis, lebih memiliki work-life balance yang baik.

2. Ciri-ciri pribadi

Background pribadi yang baik dan harmonis dapat mempengaruhi bagaimana seorang pekerja dapat membentuk work-life balance yang baik. Oleh karena dapat dapat menghindari perseteruan antara kehidupan pribadi dengan pekerjaan di kantor.

3. Ciri-ciri pekerjaan

Model kerja, beratnya pekerjaan dan lamanya waktu yang digunakan untuk bekerja dapat berakibat pada timbulnya perseteruan. Ini berlaku pada perseteruan pribadi maupun pekerjaan.

4. Attitude

Bagaimana tiap pekerja menyikapi perseteruan yang dapat terjadi antara kehidupan pribadi dengan kehidupan prosenional. Apabila ia secara positif menghadapinya, makai a tidak akan mengalami kesulitan dalam mewujudkan work-life balance. Namun apabila negative menyikapinya, maka worklife balance tidak akan terwujud. Sikap para pekerja merupakan salah satu faktor yang dapat mempengaruhi work-life balance.

Adapun karateristik yang mampu menopang work life balance adalah; karateristik kepribadian, seprti halnya siapa dirinya, dimana ia dilahirkan, apakah dia lahir dari pribadi yang hangat dan harmonis, apakah dia dibesarkan dengan cinta kasih, apakah ia produk dari pribadi yang bahagia. Semua variable ini akan mendorong ia menjadi pribadi yang bahagia. Sementara karakteristik di-mana ia dibesarkan; seperti halnya aspek penting komunikasi di dalam pribadi, cara penanggulan-gan perseteruan didalam pribadi, lalu aspek kepeduliaan dalam pribadi, aspek saling percaya dan 
menghormati, dan aspek saling mensupport satu sama lain yang pada gilirannya akan membentuk karakter yang lebih seimbang bagi orang tersebut.

Adapun karateristik dari pekerjaan; misalnya pola kerja, keadaan kerja, beban kerja, jumlah waktu bekerja, serta jalur karir yang jelas dan kontruktif mampu membuat pribadi pekerja menjadi seimbang. Terakhir dalam aspek work life balance adalah sikap mental. Antara lain; adanya daya juang, kemandirian, rasa peduli, tidak pernah merasa menyerah serta kebaikan hati sebagai modal hidup seimbang didalam pribadi maupun pekerjaannya.

Work Life Balance merupakan suatu kondisi dimana seorang pekerja dalam kondisi yang seim-bang lahir bathin, antara kegiataan yang dilakukan di dalam kontekstual kerja dan kehidupan pribadi, sehingga seseorang dapat bekerja secara optimal dan memiliki kehidupan pribadi yang Ba-hagia. Seseorang tidak saja fokus mengerjakan apa yang kerjakan di ruang lingkup dimana ia beker-ja, tetapi juga memiliki kehidupan yang seimbang antara fleksibelitas hidup, bersosialisasi, me-meliki hobi, memiliki ruang lingkup pertemanan, kehidupan yang menyenangkan lainnya di luar lingkup pekerjaan sehari-hari. Dalam kesehariannya dapat mengekspresikan diri mengerjakan apa yang ia minati, tetapi juga memiliki produktivitas kerja yang tinggi, karena pribadi yang bahagia dapat mengaktualisasikan kemampuannya secara optimal dalam unjuk kerjanya.

Keseimbangan hidup yang baik mampu menjadi tumpuan dan memiliki muatan yang positif da-lam pelaksanaan tugas-tugasnya di ruang kerja, jarang sekali orang yang memiliki keseimbangan hidup melakukan konflik-konflik kecil maupun besar di luar maupun di dalam pekerjaannya.

Kondisi yang seimbang dalam kehidupan seseorang dapat berpengaruh besar terhadap semua hal yang dimilikinya, antara lain kondisi hati di tempat ia bekerja, sehingga dapat menciptakan sua-sana bathin yang menyenangkan serta memberikan output yang positif (Parkes \& Langford, 2008). Definisi yang utuh darti konsep keseimbangan hidup dalam lingkup pekerjaan adalah, keseim-bangan psikologis di tempat kerja yang berdampak pada meningkatnya tingkat komitmen dalam bekerja, loyalitas kerja yang baik terhadap perusahaan, mudahnya mengurangi kecemasan kerjas dalam pekerjaan, selarasnya antara pikiran dan hasil kerja serta optimalisasi kerja yang tinggi da-lam melaksanakan semua jenis pekerjaan yang dikerjakannya. Hal mana menjadi esensial, karena keselarasan kedua hal antara keseimbangan, volume pekerjaan, kegiataan non pekerjaan, sehingga memberikan dampak psikologis yang positif untuk tujuan organisasi (Salam \& Abbasi, 2015).

Bentuk dari keseimbangan kehidupan pekerjaan dengan kehidupan pribadi yang baik adalah, munculnya rasa percaya diri yang tinggi sebagai manifestasi ungkapan rasa bahagia terbebas dari tekanan dan memiliki landasan kebahagiaan dalam mengerjakan sesuatu dengan kesungguhan. Sebagai mana yang diharapakan, walaupun tuntutan kerja yang tinggi, volume kerja yang luar biasa, tugas yang menumpuk, tanggung jawab yang besar, tetapi seseorang tidak merasa terpaksa dalam mengerjakannya, dikarenakan adanya kebahagiaan dalam mengerjakannya. Hal ini dapat timbul, karena antara ekspektasi yang diharapkan dengan apa yang didapatkan sangat memadai. Keseimbangan ini, diharapkan menjadi titik tumpu bagi sebuah organisasi untuk mencapai tujuan yang optimal. Bisa dibayangkan, apabila semua pekerja memiliki keseimbangan hidup yang baik, maka dapat menciptkan ethos kerja yang baik dalam menopang kinerja organisasi secara keseluruhan.

Keseimbangan kehidupan yang diciptakan antara pekerjaan dan kehidupan pribadi mampu meningkatakan unjuk kerja yang baik dalam menyeimbangkan keduanya yaitu antara harapan kualitas di dalam pekerjaan dengan terpenuhinya keseimbangan pribadi. Seseorang yang dapat menyeimbangkan tugas dan perannya di dalam pekerjaan dan kehidupan pribadi dengan baik, walau-pun seseorang dibebani pekerjaan yang berat, tanggung jawab yang besar serta tuntutan pekerjaan yang tinggi, ia mampu menanggulangi semua permasalahan pekerjaannya serta dengan mudah memberikan unjuk kerja yang baik. Pribadi tersebut mampu mengerjakan keseluruhan pekerjaan dengan penuh integritas dan motivasi yang tinggi. Dalam unjuk kerja, baik dalam lembaga maupun kepuasan psikologis, seseorang tersebut memiliki kemampuan menyeimbangkan antara kewajiban, kebutuhan menjalani hidup yang seimbang, karena dengan menjalani kedua fungsi sosial ini wa- 
laupun berbeda, apabila kebutuhan dan tuntutan seorang tersebut sudah terpenuhi, maka sebagai indikator bahwaorang tersebut seimbang dalam kehidupan kerja dan kehidupan pribadi (work-life balance) (Schemerhorn, 2005).

Ketidak seimbangan seseorang dapat dikategorikan sebagai rendah, apabila ia melakukan sesua-tu secara terpaksa, tingginya tingkat absensi dan selalu melakukan berbagai kesalahan dalam bekerja, sehingga menimbulkan berbagai kemunduran dalam pencapaian tujuan organisasi. Untuk itu pentingnya menciptakan kondisi yang seimbang, agar tercipta kondisi yang menyenangkan un-tuk bekerja, ditambah kondisi lingkungan pribadi yang menyenangkan mampu memunculkan kinerja kerja yang luar biasa tinggi, adanya keseimbangan antara keduanya; keterlibatan antara peran kerja dan kehidupan pribadi yang menyenangkan mampu memunculkan kebahagiaan kerja yang optimal, seperti halnya memiliki hobi, rekreasi, hidup bersosialisasi, bertemu dengan teman-teman dan sahabat. Hal ini akan berdampak sangat baik pada seseorang, karena dalam kesimbangan ini akan berpengaruh pada kehidupan dari seseorang dalam suatu Lembaga maupun di kehidupan seseorang sehari-hari. Apa yang terjadi di lingkungan pekerjaan dimana seseorang bekerja dapat menjalani kehidupan seimbang di lingkungan dimana ia bekerja dan di luar peker-jaannya seperti pergi ke alam terbuka, pergi berekreasi, berkumpul dalam suatu pertemanan, hal ini berdampak positif bagi seseorang di mana dalam keseimbangan tersebut akan mempengaruhi ke-hidupan dari pekerja dalam suatu lembaga maupun perannya di luar lembaga (Greenhaus, 2002).

Work life balance merupakan ketrampilan seseorang dalam menyeimbangkan berbagai hal yang bersamaan antara tuntuntan dalam hidup dan tuntutan pekerjaan, dimana seseroang dalam mengerjakan keduanya dengan peran ganda yang baik, sebagai seorang pekerja maupun sebagai pribadi yang baik (Hudson, 2005). Keseimbangan dalam mengerjakan keduanya, seseorang dapat mengerjakan keduanya dalam menjalankan tuntutan pekerjaan dan tuntutan kehidupannya, mam-pu mengatur waktu, mengatur keduanya dengan baik. Dalam menjalankan tuntutan dalam kehidupannya, seseorang wajib mampu mengatur keduanya dengan simultan dan baik dan menjalan-kan banyaknya peran yang ia hadapi sebagai individu dan sebagai pekerjayang baik (Greenhaus, 2002).

Berlandaskan pernyataan-pernyataan di atas, dapat diambil suatu kesimpulan, bahwa antara beberapa peran dalam pekerjaan dan kehidupan pribadi sehari-hari, harus menimbulkan dampak konflik yang rendah sebagai indicator rendahnya tingkat tekanan keduanya bagi orang tersebut. Keseimbangan juga dikaitkan dengan ketahanan mental seseorang dalam menanggulangi semua permasalahan untuk bertahan hidup secara mental serta memiliki konsistensi dalam menjalankan kedua belah peran dengan baik dan seimbang. Hal mana dapat dilihat dari baik buruknya kinerja seseorang dalam menjalankan keseluruahan pekerjaannya. Berdasarkan terminologi diatas dapat dijabarkan, bahwa keseimbangan antara peran di pekerjaan dan di kehidupan sehari-hari dimana rendahnya konflik yang timbul antara peran di tempat kerja dengan peran dalam kehidupan sehari-hari. Keseimbangan mampu bertahan dan menyelaraskan keharmonisan dalam kehidupan di tem-pat kerja maupun peran di lingkungan ia berada. Seorang juga akan mendapatlam keberhasilan da-lam kehidupan pribadi maupun dalam kehidupan kerja yang memuaskan apabila keterlibatan antara waktu dan perannya berjalan dengan baik.

\section{Peningkatan Karir}

Peningkatan karir adalah proses menilik potensi pekerja dan membantu pekerja untuk me-rencanakan karir pekerja di perusahaan untuk masa depan yang lebih baik (Abdullah, 2016). Pengembangan karier adalah proses peningkatan kemampuan kerja individu yang dicapai dalam rangka mencapai karier yang diinginkan (Sudiro 2011). Pengembangan karier merupakan suatu keadaan yang menunjukkan adanya sebuah pengembangan-pengembangan tingkatan pekerja pada suatu lembaga dalam jalur karier yang telah ditetapkan dalam lembaga yang berkaitan (Martoyo 2007). Seperti telah disebut di uraian diatas dapat disimpulkan pengembangan karier merupakan tanggung jawab suatu lembaga yang menyiapkan pekerja dengan kualifikasi dan pengalaman terten-tu, agar pada saat dibutuhkan lembaga sudah memiliki pekerja dengan kualifikasi tertentu. 
Peningkatan karir adalah peningkatan pribadi yang dilakukan pekerja untuk mencapai suatu rancangankarir serta peningkatan oleh departemen HR untuk mencapai suatu rancangankerja sesuai dengan jalur atau jenjang lembaga (I Komang A, et. Al. 2012). Peningkatan karir adalah upaya yang dilakukan oleh lembaga dalam merencanakan karir pegawainya yang dimaksudkan sebagai manajemen karir, antara lain merencanakan, melaksanakan, dan mengawasi karir (Sinambela 2015).

Dalam peningkatan karir diperluka rancangan dan strategi agar apa yang diharapkan dapat ter-penuhi sesuai dengan target. Rancangan program dalam peningkatan karir dibedakan dalam tiga tahapan (Samsudin 2010) yaitu:

\section{Tahap Perencanaan}

Tahap penyelarasan perencanaan karir pekerja dengan karir perusahaan untuk mengidentifikasi kelemahan dan kekurangan pekerja dalam melaksanakan tugas yang diberikan.

2. Tahap Pengarahan

Tahap untuk membantu mengarahkan para pekerja agar mampu mewujudkan perencanaan karirnya agar terwujud. Pengarahan melalui konseling atau pendekatan menggunakan pelayanan informasi.

3. Tahap Pengembangan

Tahap ini mengembangkan kreativitas dan inistiatifnya untuk menduduki jenjang lebih tinggi pada masa mendatang. Adapun beberapa cara apat dilakukan seperti pengawasan, training, perputaran jabatan, dan program beasiswa.

\section{Tekanan Kerja}

Tekanan kerja adalah masalah yang dialami pekerja, yang diakibatkan oleh kelebihan kerja, merasa tidak nyaman ketika bekerja, dan rendahnya rasa ketidakpuasan. Hal tersebut akan berpengaruh pada menurunnya produktivitas di tempat kerja. Tekanan kerja adalah suatu keadaan tegang yang mengakibatkan adanya ketidakseimbangan fisik dan psikis, yang mempengaruhi perasaan, konsentrasi, dan kondisi seorang pekerja. Tekanan kerja pada pekerjaan adalah pengalaman tekanan kerja yang berhubungan dengan pekerjaan.

Tekanan kerja merupakan reaksi tubuh apabila mengalami tekanan sehingga terjadi ketid-aknyamanan secara psikologis. Reaksi yang dapat timbul dapat berupa jantung berdebar, mudah marah, kesulitan konsentrasi, pusing kepala, asma, keringat berlebih, gangguan pencernaan, haid tidak teratur, gangguan kulit, sariawan dan masih banyak reaksi tubuh lainnya.

\section{Penyebab Tekanan kerja di Tempat Kerja}

Dengan mengetahui penyebab tekanan kerja, maka kita dapat terhindar dari tekanan kerja. Kadangkadang tekanan kerja berkepanjangan terjadi tanpa si penderita tekanan kerja mengetahuinya dan berlangsung bertahun-tahun sehingga penanganannya sudah terlambat.

Tekanan kerja di lingkungan kerja yang umum terjadi adalah:

1. Working hours yang panjang

2. Pekerjaan kantor yang overload atau berat

3. Struktur lembaga yang berubah

4. Deadline pekerjaan yang sempit

5. Work atmosphere kurang nyaman

6. Tugas yang membosankan dan berulang-ulang

7. Skill kurang memadai dalam job description diberikan

8. Kerjasama yang kurang harmonis dengan kolega kerja maupun supervisor

9. Peralatan kerja yang kurang memadai

10.Pendapatan dan problema finansial

Awal tekanan kerja pada tiap individu bervariasi. Apabila gejalanya ringan, pada umumnya tidak terlihat. Namun pada gejala tekanan kerja yang berat, biasanya akan terlihat jelas. Apabila tidak ditangani dengan cepat, maka akan menjadi gejala yang lebih serius. Bahkan dapat menuju kepada gejala suicidal atau bunuh diri. 
Memahami cara menghilangkan tekanan kerja di tempat kerja sangat membantu agar kita lebih tenang dan bahagia saat bekerja. Ini akan mendorong produktivitas kerja Anda sehingga karir dapat berkembang lebih.

\section{Produktivitas}

Produktivitas kerja merupakan kemampuan pekerja dalam mencapai target perusahaan yang telah ditetapkan (Tanjung et al., 2018). Produktivitas adalah perbandingan antara hasil dengan ma-sukan. Jika Produktivitas meningkat dimungkinkan oleh adanya peningkatan efisiensi (waktu-bahan-tenaga). Produktivitas kerja adalah kemampuan pekerja dalam produktivitas dibandingkan dengan tenaga atau input yang digunakan. Seorang pekerja dapt dikatakan produktif apabila mampu menghasilkan barang atau jasa sesuai dengan diharapkan dalam waktu yang singkat atau tepat. Jadi tenaga yang dikeluarkan menghasilkan output yang lebih, maka dapat disebut sebagai produktif.

Keadaan-keadaan yang mempengaruhi produktivitas, antara lain:

1.Kondisi dari pekerjaan

Pekerjaan yang memerlukan banyak aktivitas dan melelahkan dapat mengakibatkan produktivitas kerja menjadi rendah. Agar gerakan yang digunakan dalam melakukan peker-jaan cepat dan tepat terlebih dahulu diadakan "Time and Motion Study". Dua studi tersebut dapat tercipta gerakangerakan yang efektif dapat memperlancar pekerjaan sekaligus men-gurangi kesalahan pekerja.

2.Kondisi dari Pekerja itu sendiri.

Semangat dan kegairahan kerja para pekerja merupakan unsur penting guna mencapai produktivitas yang tinggi. Maka sebaiknya pimpinan memperhatikan unsur penting tersebut seperti melalui:

- Pendapatan cukup

- Kebutuhan pekerja diutamakan

- Penempatan pekerja pada jenjang yang tepat, sesuai dengan kemampuan pekerja

Faktor-faktor lain selain dari kedua kondisi tersebut diatas ada juga yang dapat mempengaruhi produktivitas kerja adalah:

\section{Kerangka Pemikiran}

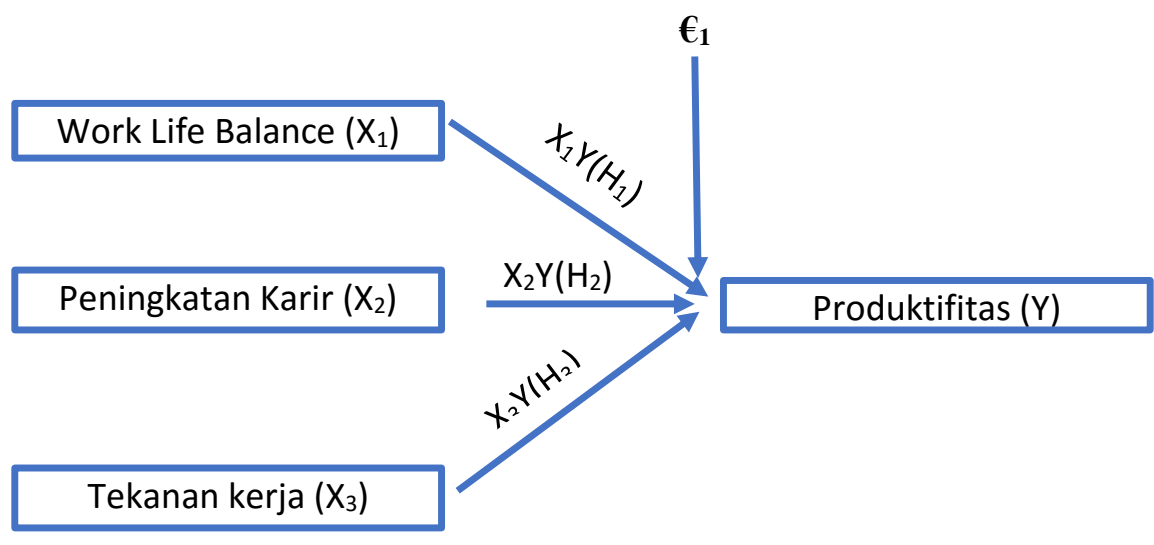

Gambar 1. Kerangka Riset

Sumber: Data Primer, SmartPLS 3.0, 2021

\section{Hipotesis Riset}

Dalam riset, penulis merumuskan hipotesis riset ini dengan menggunakan pendekatan kuantitatif. Hipotesis yang penulis dapatkan dari data diatas adalah sebagai berikut:

H1 : Work Life Balance Berpengaruh Positif dan Signifikan terhadap Produktivitas

H2 : Peningkatan Karir Berpengaruh Positif dan Signifikan terhadap Produktivitas

H3 : Tekanan kerja Berpengaruh Positif dan Signifikan terhadap Produktivitas 


\section{Metode penelitian}

Metodologi yang digunakan dalam riset ini adalah berbasis pada penybaran kuesioner secara daring serta wawancara pada narasumber sebagai data primer. Alat untuk mengukur validitas riset ini adalah SmartPLS3, sehingga dapat dianalisis seberapa jauh korelasi dari masing-masing variabel menggunakan pengukuran. Variabel eksogen dalam riset ini adalah Work Life Balance (X1), Peningkatan Karir (X2) dan Tekanan kerja (X3) Sedangkan Variabel endogen dalam riset ini adalah Produktivitas (Y). Populasi riset ini adalah pekerja LSP P3 PIB - BNSP. Riset ini menggunakan Probability sampling dengan cara simple random sampling. Pengumpulan pendapat responden da-lam riset ini menggunakan Kuesioner, penyebaran kuesioner dilakukan melalui Google Form serta dengan metode tanya jawab atau wawancara menggunakan teleconference applikasi Zoom selama masa PSBB. Riset ini mengambil sampel sebanyak 100 pekerja yang tergolong sebagai data primer. Data yang sudah dikumpulkan diolah menggunakan program SmartPLS 3.0 untuk mengetahui apakah data tersebut patut untuk dianalisis. Uji yang dimaksud terdiri dari Uji validitas, Uji reabili-tas, Hierarchial Component Model (HCM). Setelah itu, Data yang lolos dalam uji tersebut dianalisis menggunakan Uji kecocokan model (Uji fit), diagram jalur riset dan uji hipotesis.

\section{Hasil dan Pembahasan}

\section{Uji Validitas dan Reabilitas}

Pada uji validitas dan Reabilitas seluruh item pernyataan untuk variabel yang di uji memiliki nilai lebih besar > 0,5. Sehingga dapat dinyatakan bahwa item pernyataan untuk seluruh variabel adalah valid. Serta pada uji reabilitas dapat dilihat nilai Cronbach's Alpha dari masing-masing variabel memiliki nilai rata-rata > 0,7 maka indikator pernyataan dari masing-masing variabel dapat dinyatakan reliabel dan dapat di terima.

\section{Uji Hierarchical Component Model (HCM)}

Tabel 1. Hierarchical Component Model

\begin{tabular}{|c|c|c|}
\hline Variabel & $\begin{array}{c}\text { Path } \\
\text { Coefficients }\end{array}$ & R Square \\
\hline Work Life Balance (X1) & 0,351 & 0,845 \\
\hline Peningkatan Karir (X2) & 0,309 & 0,845 \\
\hline Tekanan kerja (X3) & 0,294 & 0,845 \\
\hline
\end{tabular}

Sumber: Data Primer, SmartPLS 3.0, 2021

$R$ Square atau disebut determinasi pada tabel hierarchical component model untuk mengetahui seberapa besar kontribusi X terhadap Y berdasarkan tabel 1 nilai $R$ Square 0,845 atau 84,5\% produktivitas kerja pekerja di pengaruhi oleh work life balance, peningkatan karir, dan tekanan kerja sedangkan sisanya sebesar $15,5 \%$ di pengaruhi oleh faktor-faktor lain yang tidak termasuk dalam riset ini.

Uji kecocokan model (Uji Fit)

Tabel 2. Uji Fit

\begin{tabular}{|l|c|c|c|}
\hline Ukuran & Hasil & Kriteria & Keterangan \\
\hline SRMR & 0,055 & $<0.08^{\mathrm{a}}$ & Model Fit \\
\hline NFI & 0,923 & $>0.90^{\mathrm{b}}$ & Model Fit \\
\hline rms Theta & 0,105 & $<0.12^{\mathrm{a}}$ & Model Fit \\
\hline
\end{tabular}

Sumber: Data Primer, SmartPLS 3, 2021 
Tabel 2 dapat disimpulkan bahwa model regresi layak digunakan dalam riset mengenai work life balance, peningkatan karir, dan tekanan kerja terhadap produktivitas.

\section{Diagram Jalur Riset}

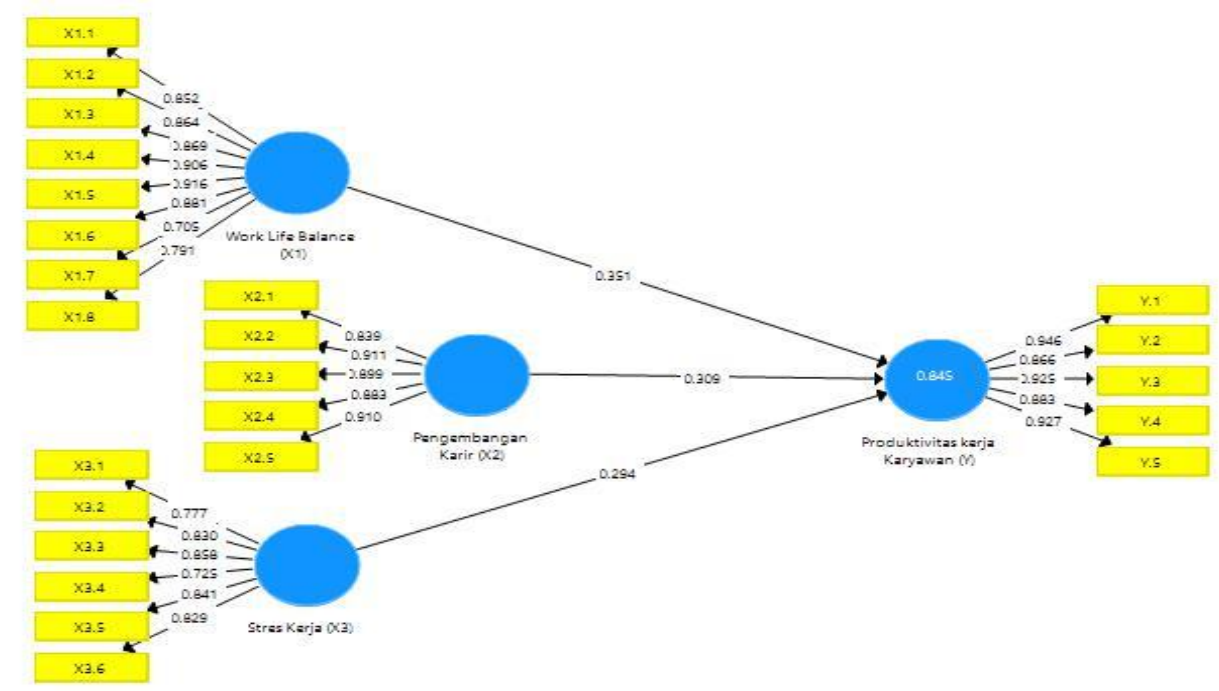

Gambar 2. Diagram Jalur Riset

Sumber: Data Primer, SmartPLS 3, 2021

Uji Hipotesis

\begin{tabular}{|c|c|c|c|}
\hline Indikator & T-Statistic & P-Values & Signifikansi \\
\hline X1.1 <- Work Life Balance & 21,205 & 0,000 & Signifikan \\
\hline $\mathrm{X} 1.2<-$ Work Life Balance & 19,794 & 0,000 & Signifikan \\
\hline $\mathrm{X} 1.3<-$ Work Life Balance & 21,071 & 0,000 & Signifikan \\
\hline X1.4<- Work Life Balance & 31,598 & 0,000 & Signifikan \\
\hline X1.5 <- Work Life Balance & 40,230 & 0,000 & Signifikan \\
\hline X1.6 <- Work Life Balance & 23,867 & 0,000 & Signifikan \\
\hline X1.7 <- Work Life Balance & 6,813 & 0,000 & Signifikan \\
\hline X1.8<- Work Life Balance & 12,885 & 0,000 & Signifikan \\
\hline X2.1 <- Peningkatan Karir & 14,365 & 0,000 & Signifikan \\
\hline X2.2<- Peningkatan Karir & 39,657 & 0,000 & Signifikan \\
\hline X2.3<- Peningkatan Karir & 26,651 & 0,000 & Signifikan \\
\hline X2.4 <- Peningkatan Karir & 24,091 & 0,000 & Signifikan \\
\hline X2.5 <- Peningkatan Karir & 33,533 & 0,000 & Signifikan \\
\hline X3.1<- Tekanan kerja & 11,403 & 0,000 & Signifikan \\
\hline X3.2<- Tekanan kerja & 11,379 & 0,000 & Signifikan \\
\hline X3.3<- Tekanan kerja & 16,818 & 0,000 & Signifikan \\
\hline X3.4<- Tekanan kerja & 9,398 & 0,000 & Signifikan \\
\hline X3.5<- Tekanan kerja & 18,422 & 0,000 & Signifikan \\
\hline
\end{tabular}




\begin{tabular}{|l|l|l|l|}
\hline X3.6 <- Tekanan kerja & 10,897 & 0,000 & Signifikan \\
\hline Y1.1 <- Produktivitas & 62,628 & 0,000 & Signifikan \\
\hline Y1.2 <- Produktivitas & 14,205 & 0,000 & Signifikan \\
\hline Y1.3 <- Produktivitas & 49,191 & 0,000 & Signifikan \\
\hline Y1.4 <- Produktivitas & 21,699 & 0,000 & Signifikan \\
\hline Y1.5 <- Produktivitas & 46,244 & 0,000 & Signifikan \\
\hline
\end{tabular}

Variabel Perkembangan Work Life Balance (X1)

$\mathrm{H} 0: \rho \mathrm{YX} 1 \leq 0$ Work Life Balance tidak berpengaruh positif terhadap Produktivitas.

H1 : $\rho$ YX1 > 0 Work Life Balance berpengaruh positif terhadap Produktivitas.

Berdasarkan hasil pengolahan data diperoleh nilai koefisien jalur sebesar 0,351 dan p-value sebesar 0,000 (signifikan), artinya Work Life Balance berpengaruh signifikan dengan arah positif terhadap Produktivitas.

\section{Variabel Peningkatan Karir (X2)}

$\mathrm{H} 0: \rho Y X 2 \leq 0$ Peningkatan Karir tidak berpengaruh positif terhadap Produktivitas.

$\mathrm{H} 2: \rho Y X 2>0$ Peningkatan Karir berpengaruh positif terhadap Produktivitas.

Berdasarkan hasil pengolahan data diperoleh nilai koefisien jalur sebesar 0,309 dan p-value sebesar 0,000 (signifikan), artinya Peningkatan Karir berpengaruh signifikan dengan arah positif terhadap Produktivitas.

\section{Variabel Tekanan kerja $(X 3)$}

$\mathrm{H} 0: \rho \mathrm{YX} 3 \leq 0$ Tekanan kerja tidak berpengaruh positif terhadap Produktivitas.

$\mathrm{H} 3: \rho \mathrm{YX} 3>0$ Tekanan kerja berpengaruh positif terhadap Produktivitas.

Berdasarkan hasil pengolahan data diperoleh nilai koefisien jalur sebesar 0,294 dan p-value sebesar 0,000 (signifikan), artinya Tekanan kerja berpengaruh signifikan dengan arah positif terhadap Produktivitas.

\section{Kesimpulan}

Riset ini mempelajari korelasi antara variable-variabel Work Life Balance, Peningkatan Karir dan Tekanan kerja terhadap Produktivitas dengan Objek Riset Organisasi yang Bernama LSP P3 PIB yang bergerak di bidang Asesmen Sertifikasi BNSP dalam Skema Profesi Penyuluh Antikorupsi. Riset dilakukan secara simultan dengan berjalannya Program PPKM (Pemberlakukan Pembatasan Kegiatan Masyarakat) di Indonesia, karena tingginya angka pasien Covid19 di Indonesia, terutama di Jakarta yaitu lokasi riset domisili LSP P3 PIB.

Selamat riset dilaksanakan, para Asesi atau peserta Asesmen juga diminta untuk mengisi kuesioner yang dibagikan menggunakan Google Form. Teknik pengumpulan data primer dilakukan dengan interview melalui Aplikasi Zoom. Setelah melakukan kompilasi data, data ditabulasikan dalam bentuk excel dan segera diolah dengan menggunakan program SmartPLS 3.0. Hasil pengolahan tersebut diperoleh kesimpulan bahwa Work Life Balance (X1), Peningkatan Karir (X2), Tekanan kerja (X3) memiliki korelasi signifikan terhadap Produktivitas (Y) pada LSP P3 PIB. Selama riset berjalan, kondisi LSP P3 PIB tidak pernah terjadi keluar masuknya pekerja atau Asesor di Lembaga tersebut. Mayoritas Asesor yang bekerja di Lembaga tersebut, merasakan kebahagiaan kerja walaupun adanya beban kerja yang luar biasa berat. Pembagian kerja, proses asesmen, proses penilaian, proses Uji Kompetensi, proses bimbingan teknis, proses pengumuman kelulusan dan proses kerja lainnya. Suasana dan kondisi kerja di Lembaga tersebut, berdasarkan laporan observasi dan tanya jawab, mereka yang bekerja di Lembaga ini mendapatkan suasana kerja yang optimal, kekeluargaan, jam kerja yang fleksibel, keleluasan berpikir, dapat memberikan masukan kepada Lembaga, 
melakukan perbaharuan-perbaharuan serta merasa sangat diperhatikan oleh para Atasan serta sesa-ma Asesor lainnya. Suasana kerja yang nyaman, jenjang karier yang terstruktur, kesejahteraan yang terjamin membuat semua yang bekerja di Lembaga ini merasa diakui dan diapresiasi sebagai Asesor.

\section{Limitasi dan studi lanjutan}

Limitasi dari riset ini adalah, bahwa kajian hanya dilakukan seputar variable yang diteliti dan tidak meneliti di luar variable lain,serta jumlah responden yang terbatas serta dilaksankan pada kurun waktu kurang dari satu tahun kerja. Disarankan untuk peneliti selanjutnya untuk menambahkan beberapa variabel endogen dan eksogen lainnya; motivasi, loyalitas, dedikasi dan peningkatan produktivitas.

\section{Referensi}

Abdullah. (2016). Manajemen dan Evaluasi Kinerja Karyawan. Aswaja Pressindo. Jogjakarta. Alamsyah, D. S. I. (2019). Pengaruh Performance, Orientasi dan Peningkatan karir Terhadap Produktivitas Kerja pada pt. Gudang garam tbk. Cabang Medan. Jurnal Ilmiah Dunia Ilmu Vol, 5(1).

Ariawaty, R. R. N. (2019). Pengaruh Employee Engagement Terhadap Work-Life Balance Pekerja. BISMA, 13(2), 97-104.

Forbes (2018). The Evolving Definition of Work-Life Balance. https://www.forbes.com/sites/alankohll/2018/03/27/the-evolving-definition-of-worklife-balance/?sh=6508021c9ed3

Ganapathi, I. M. D. (2016). Pengaruh Work-Life Balance terhadap Kepuasan Kerja Pekerja (studi pada PT. Bio Farma Persero). Jurnal Ecodemica: Jurnal Ekonomi, Manajemen, dan Bisnis, 4(1), 125-135.

Greenhaus, J.H. (2002). The Relation Between Work-Family Balance and Quality of Life. www.elsevier.com/locate/jvb

Harahap, S. L. (2020). Pengaruh Lingkungan Kerja, Komitmen Profesi, Motivasi dan Tekanan kerja Terhadap Kinerja Pegawai Pada Kantor Pelayanan Pajak Pratama Pekanbaru Tampan. JMB (Jurnal Manajemen dan Bisnis), 2(1), 70-76.

Hudson. (2005). The Case for Work Life Balance - Closing Gap Between Policy and Practice. 20:20 Series, Australia.

I Komang. (2012). Manajemen Sumber Daya Manusia. Penerbit Graha Ilmu, Jogjakarta.

Kurnia, E., Daulay, R., \& Nugraha, F. (2019). Dampak Faktor Motivasi dan Fasilitas Kerja Terhadap Produktivitas Pada Badan Usaha Milik Negara di Kota Medan. In Prosiding Seminar Nasional Kewirausahaan (Vol. 1, No. 1, pp. 365-372).

Martoyo. (2007). Manajemen Sumber Daya Manusia. BPFE - Yogyakarta

Parkes, L. P., \& Langford, P. H. (2008). Work-life balance or work-life alignment? A test of the importance of work-life balance for employee engagement and intention to stay in organizations. Journal of Management \& Organization, 14(3), 267-284

Salam \& Abbas. (2015). Impact of Life and Job Domain Characteristics on Work Life Balance of Textile Employees in Pakistan. https://www.researchgate.net/publication/288828970_IMPACT_OF_LIFE_AND_JOB_ DOMAIN_CHARACTERISTICS_ON_WORK_LIFE_BALANCE_OF_TEXTILE_E MPLOYEES_IN_PAKISTAN

Samsudin (2010). Manajemen Sumber Daya Manusia. Bandung Penerbit Pustaka Setia.

Schabracq, Marc J., Jacques A.M. Winnubst, dan Cary L. Cooper (2017), The Handbook of Work and Health Psychology, Williem Maxwell.

Schemerhorn. (2005). Organizational Behaviour. John Wiley \& Son. Inc.

Sinambela. (2015). Manajemen Sumber Daya Manusia. PT. Bumi Aksara, Jakarta.

Sudiro. (2011). Perencanaan Sumber Daya Manusia. UB Press. Malang, Indonesia.

Sutrisno, S., \& Suhendi, D. A. (2019). Pengaruh Tekanan kerja Terhadap Kinerja Pekerja Pada PT. Bangun Sinar Indonesia Jakarta. Jurnal Ekonomi Efektif, 1(2).

Tanjung (2018). https://stiealwashliyahsibolga.ac.id/jurnal/index.php/jesya/article/view/8

Wuarlima, F., Kojo, C., \& Sendow, G. M. (2019). Pengaruh Keseimbangan Kehidupan Kerja, Keterlibatan Kerja Dan Peningkatan karir Terhadap Kepuasan Kerja Pekerja Pada Gran 
Puri Hotel Manado. Jurnal EMBA: Jurnal Riset Ekonomi, Manajemen, Bisnis dan Akuntansi, 7(4). 